\title{
USE OF "THE LOWEST PRICE" AWARD CRITERION IN THE PUBLIC PROCUREMENT IN ROMANIA
}

\author{
Ionel PREDA \\ The Bucharest University of Economic Studies, Romania \\ predaionel4@gmail.com \\ Cezar-Petre SIMION \\ The Bucharest University of Economic Studies, Romania \\ cezar.simion@man.ase.ro
}

\begin{abstract}
Taking into account the very large sums being spent through the Romanian public procurement system (approximately $8 \%$ of the GDP), analysing the award criteria used in the procurement procedures is an important element that influences the achievement of the economic and social efficiency of procurement. The article describes the criteria for public procurement award in Romania, focusing on the most used criterion, namely the lowest price. It also presents the advantages and disadvantages of using this criterion, statistical situations at national and European level, the difficulties encountered in using this criterion by contracting authorities and the vulnerabilities of tenderers participating in the procurement procedures which use for the award the criterion under consideration.
\end{abstract}

Keywords: public procurement, procurement procedure, awarding criterion, lowest price, technical specifications.

\section{INTRODUCTION}

In establishing the evaluation criteria, a number of factors need to be taken into consideration, including the characteristics of contracting authorities needs, the capacity to define demands clearly and concisely and to select the relevant factors for tender evaluation (Thai et al., 2009). The opinion of Thai et al., (2009) is that an assessment plan should be made for the performance of the evaluation process. The main objectives of this assessment plan are the following:

- the awarding criterion;

- the evaluation factors;

- the method for selecting the successful tenderer;

- the formula for the score calculation (Thai et al., 2009). 
These authors enumerate several evaluation factors used in public procurement from the United States, namely: demonstrating similar experience in the procurement domain, the qualifications of the management team, the after-sales service and warranty and the method for reporting of the results.

In many cases, the lowest price criterion isn't enough for the identification of the best tender. There are other evaluation factors that may be considered, typically features of the acquired product or services related with the delivery of the products. The more complex the procurements are, more non-price factors are becoming very important in the proccess of tender evaluation. Low cost pricing award procedures are suitable for products or services where price is the one and only relevant factor (food, electricity and office equipment) (Dimitri et al., 2006).

The lowest price is the traditional and most frequent method that is utilised in the vast majority of public procurement regulations (Soudry, 2004).

If it is critical to accomplish a specific quality level, then lowest price criterion (with minimum quality specifications) is a very efficient method for supplier selection. When the awarding criterion is the lowest price, a dedicated scoring rule isn't necessary (Bergman and Lundberg, 2013). The same opinion is shared by Carpineti, Piga and Zanza, (2006).

In some cases the government may take into consideration other criteria except the lowest price. For instance past performance records, qualifications of personnel and technical capabilities (Cummings and Qiao, 2003).

If the lowest price is the awarding criterion, there isn't much to say about winning strategy of the tenderer (Chen, 2008). Each tender will want to meet only the minimum technical requirements and tender the lowest price. Tenderers will not offer technical specifications higher than those specified in the tender book, because these mean higher prices.

In the European Union the awarding criterion can be either the most economically advantageous tender or the lowest price. The first awarding criterion is a broader category that is referring to the relation between price and quality (Morgan and Sonnino, 2006).

In the situation when the cost of achieving the required quality is known and when several tenders can meet the demanded quality, transaction costs will be minimised if lowest price is utilised as awarding criterion (Bergman and Lundberg, 2013).

\section{AWARD CRITERIA IN PUBLIC PROCUREMENT PROCEDURES IN ROMANIA}

The forms of award criteria, according to Romanian Law no. 98/2016 on public procurement, are:

- the best quality - cost ratio; 
- the best quality-price ratio;

- the lowest cost;

- the lowest price.

The advantages of using the lowest price criterion are:

- does not let the public authority to demonstrate flexibility throughout the award procedure;

- requires a very strict financial discipline;

- sometimes services or products acquired are of poor quality;

- in some situations the "lowest cost" criterion is more relevant, mostly when is analised the exploitation of acquired goods throughout longer time periods;

- requires the public authority to make sure that the conditions about the professional, technical and financial capacity of the bidders are satisfied.

The disadvantages of using the lowest price criterion are:

- quantifiable and objective criterion;

- affordable and convenient criterion which requires the selection of the lowest price tender after all participation conditions are satisfied;

- virtually eliminates the possibility of contesting the result of the award procedure;

- the public authority can obtain the minimum price that the market can provide;

- the reduction of the tender evaluation period.

\section{DETERMINING TECHNICAL SPECIFICATIONS}

Determining technical specifications is the stage of the public procurement process in which the technical properties and characteristics of the products / services to be procured are established.

According to Law no. 98/2016 on public procurement, technical specifications are the requirements, prescriptions, technical characteristics that allow each product, service or work to be objectively described in a manner appropriate to the contracting authority's needs.

Lowest-price tender assessment is straight-forward, but often in practice is very difficult to define proper minimum quality specifications (Bergman and Lundberg, 2013).

Applying the lowest price award criterion first involves the fulfilment by the products or services tendered of the technical specifications requested by the contracting authorities, but the manner in which the technical requirements are set differs depending on the type of procedure and the country in which it is carried out. 
For example, in Romania, according to Law no. 98/2016 on public procurement, the technical specifications may be established in the following ways:

a) by reference to performance requirements or functional requirements;

b) by reference to technical specifications, national standards transposing European standards, European technical assessments, common technical specifications, international standards;

c) by reference to performance requirements or functional requirements and by reference to technical specifications;

d) by reference to technical specifications and by reference to performance requirements.

Determining technical specifications may be a difficult process. While in the case of a vehicle purchase, the technical specifications are relatively easy to set up (transport capacity - number of seats, engine capacity, suspension type, safety and comfort - number of airbags, air conditioning, trunk volume, pollutant norm etc) there are situations in which these specifications are very difficult to establish in detail since the initiation of the procedure.

For example, in Belgium, technical specifications for military procurement are difficult to determine for complex equipment that has been used over many years. In the case of products such as airplanes or tanks, the purchasers first establish some "basic" specifications, and then, after contracting, they modify these specifications (Baeyens and Martel, 2007).

In Singapore, it is not allowed to discuss technical specifications with potential suppliers prior to initiating the procurement procedure (Jones, 2007), while in the EU, this is allowed through a transparent market consultation, the outcome of which is published in the Electronic Public Procurement System (SEPA), obliging the contracting authority not to restrict competition through the specifications established after this consultation. In fact, the authors Erridge and Nondi, (1994) concluded that consulting suppliers prior to initiating the procurement procedure is a solution for setting technical specifications.

Technical specifications are very difficult to establish when purchasing innovative products or for some sustainability requirements (Thai et al., 2009) or when using a procurement procedure such as the Romanian innovation partnership.

The situation of establishing technical specifications that are too precise and detailed is often criticized (Thai et al., 2009). A relevant example in this regard are the technical specifications for the purchase of hot chocolate for the US Army which have 20 pages (Gansler, 1989). Excessive technical specifications make it very difficult for the interested companies to develop their tenders, for the tender evaluation process, contract performance and ordered products acceptance. 


\section{USE OF "THE LOWEST PRICE" AWARD CRITERION IN THE PUBLIC PROCUREMENT IN ROMANIA}

The number of award procedures developed in Romania in 2017 was 19,923. Their estimated values are shown in Table 1.

TABLE 1. ESTIMATED VALUES FOR AWARD PROCEDURES

IN ROMANIA IN 2017

\begin{tabular}{|c|c|c|c|c|}
\hline No. & Procedure type & $\begin{array}{c}\text { Number of } \\
\text { procedures }\end{array}$ & $\begin{array}{c}\text { Estimated value } \\
\text { (thousand lei, } \\
\text { excluding VAT) }\end{array}$ & Weight \\
\hline 1 & Open bid & 6,332 & $45,285,681.38$ & $75.57 \%$ \\
\hline 2 & Restricted bid & 43 & $1,634,353.31$ & $2.73 \%$ \\
\hline 3 & Negotiation & 81 & $2,946,552.99$ & $4.92 \%$ \\
\hline 4 & Call for tenders / Simplified procedure & 13,467 & $10,060,512.94$ & $16.79 \%$ \\
\hline & Total award procedures & 19,923 & $\mathbf{5 9 , 9 2 7 , 1 0 0 . 6 2}$ & $100 \%$ \\
\hline
\end{tabular}

Source: (Romanian National Agency for Public Procurement - ANAP, 2017)

It can be noticed that the highest estimated values were those of open tender procedures $(45,285,861$ thousand lei, VAT excluded, weight $75.57 \%)$ and the simplified procedure $(10,060,512$ thousand lei, VAT excluded, weight 16.79\%).

According to the award criteria, the number of procurement procedures carried out in Romania in 2017 is shown in Table 2.

TABLE 2. NUMBER OF PROCUREMENT PROCEDURES CARRIED OUT IN ROMANIA
\begin{tabular}{|c|c|c|c|}
\hline IN 2017 ACCORDING TO TYPES OF AWARD CRITERIA \\
\hline No. & Award criterion & $\begin{array}{c}\text { Number of } \\
\text { procedures }\end{array}$ & Weight \\
\hline 1 & Best quality - cost ratio & 25 & $0.13 \%$ \\
\hline 2 & Best quality-price ratio & 1,512 & $7.59 \%$ \\
\hline 3 & Lowest cost & 8 & $0.04 \%$ \\
\hline 4 & Lowest price & 18,378 & $92.25 \%$ \\
\hline & Total award procedures & 19,923 & $100 \%$ \\
\hline
\end{tabular}

Source: (ANAP, 2017)

The highest number of procurement procedures were awarded utilizing the lowest price criterion (weight $92.25 \%$ ) succeeded by the best quality-price ratio criterion (weight $7.59 \%$ ) (Figure 1). 


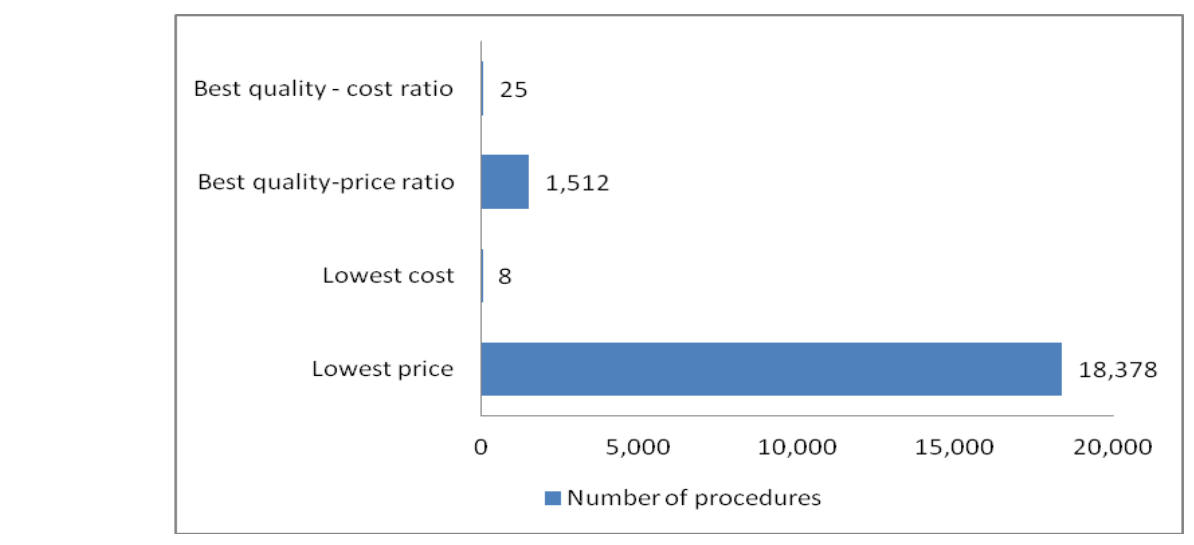

FIGURE 1: GRAPHICAL REPRESENTATION OF THE NUMBER OF PROCUREMENT PROCEDURES CARRIED OUT IN ROMANIA IN 2017 BY TYPE OF AWARD CRITERIA

Source: Based on the data in Table 2

It should be noted that as of June 2018, the Romanian National Agency for Public Procurement (ANAP) has imposed on all contracting authorities that if the estimated value of a batch exceeds the threshold of 648,288 lei, VAT excluded (for supply / products / services contracts to the procedures divided by batches), or where the estimated value of the largest subsequent contract exceeds the same threshold, the contracting authority may no longer use the lowest price criterion, which must use one of the other three award criteria. Consequently, in view of this requirement, it is to be expected in the period 20182019 for the criterion of the lowest price to decrease as compared to the other three criteria.

The degree of use of each type of award criterion for the types of procurement procedures carried out in Romania in 2017 is shown in Table 3.

TABLE 3: DEGREE OF USE OF EACH TYPE OF AWARD CRITERION BY TYPE OF PROCUREMENT PROCEDURES

\begin{tabular}{|c|c|c|c|c|c|c|c|c|c|c|}
\hline \multirow{3}{*}{ No. } & \multirow{3}{*}{$\begin{array}{c}\text { Proce- } \\
\text { dure } \\
\text { type }\end{array}$} & \multicolumn{8}{|c|}{ Award criterion } & \multirow{3}{*}{$\begin{array}{l}\text { Total } \\
\text { proce- } \\
\text { dures }\end{array}$} \\
\hline & & \multicolumn{2}{|c|}{$\begin{array}{l}\text { Best quality - } \\
\text { cost ratio }\end{array}$} & \multicolumn{2}{|c|}{$\begin{array}{l}\text { Best quality- } \\
\text { price ratio }\end{array}$} & \multicolumn{2}{|c|}{ Lowest cost } & \multicolumn{2}{|c|}{ Lowest price } & \\
\hline & & $\begin{array}{c}\text { No. of } \\
\text { procedures }\end{array}$ & Weight & $\begin{array}{c}\text { No. of } \\
\text { procedures }\end{array}$ & Weight & $\begin{array}{c}\text { No. of } \\
\text { procedures }\end{array}$ & Weight & $\begin{array}{c}\text { No. of } \\
\text { procedures }\end{array}$ & Weight & \\
\hline 1 & $\begin{array}{c}\text { Call for } \\
\text { tenders } \\
/ \\
\text { Simplifi } \\
\text { ed } \\
\text { procedu } \\
\text { re }\end{array}$ & 19 & $76 \%$ & 1,069 & $\begin{array}{c}70.70 \\
\%\end{array}$ & 6 & $75 \%$ & 12,373 & $67.33 \%$ & 13,467 \\
\hline
\end{tabular}


Preda I., Simion C.P.

USE OF "THE LOWEST PRICE" AWARD CRITERION IN THE PUBLIC PROCUREMENT IN ROMANIA

\begin{tabular}{|c|c|c|c|c|c|c|c|c|c|c|}
\hline 2 & $\begin{array}{c}\text { Negotiat } \\
\text { ion }\end{array}$ & 0 & $0 \%$ & 18 & $1.19 \%$ & 0 & $0 \%$ & 63 & $0.34 \%$ & 81 \\
\hline 3 & $\begin{array}{l}\text { Restrict } \\
\text { ed bid }\end{array}$ & 0 & $0 \%$ & 4 & $0.26 \%$ & 0 & $0 \%$ & 39 & $0.21 \%$ & 43 \\
\hline 4 & $\begin{array}{l}\text { Open } \\
\text { bid }\end{array}$ & 6 & $24 \%$ & 421 & $\begin{array}{c}27.84 \\
\%\end{array}$ & 2 & $25 \%$ & 5,903 & $32.12 \%$ & 6,332 \\
\hline \multicolumn{2}{|c|}{$\begin{array}{c}\text { Total } \\
\text { procedures }\end{array}$} & 25 & $0.13 \%$ & 1,512 & $7.59 \%$ & 8 & $0.04 \%$ & 18,378 & $92.25 \%$ & 19,923 \\
\hline
\end{tabular}

Source: (ANAP, 2017)

In Figure 2 is presented the graphical representation of the number of procurement procedures by type of award criteria.

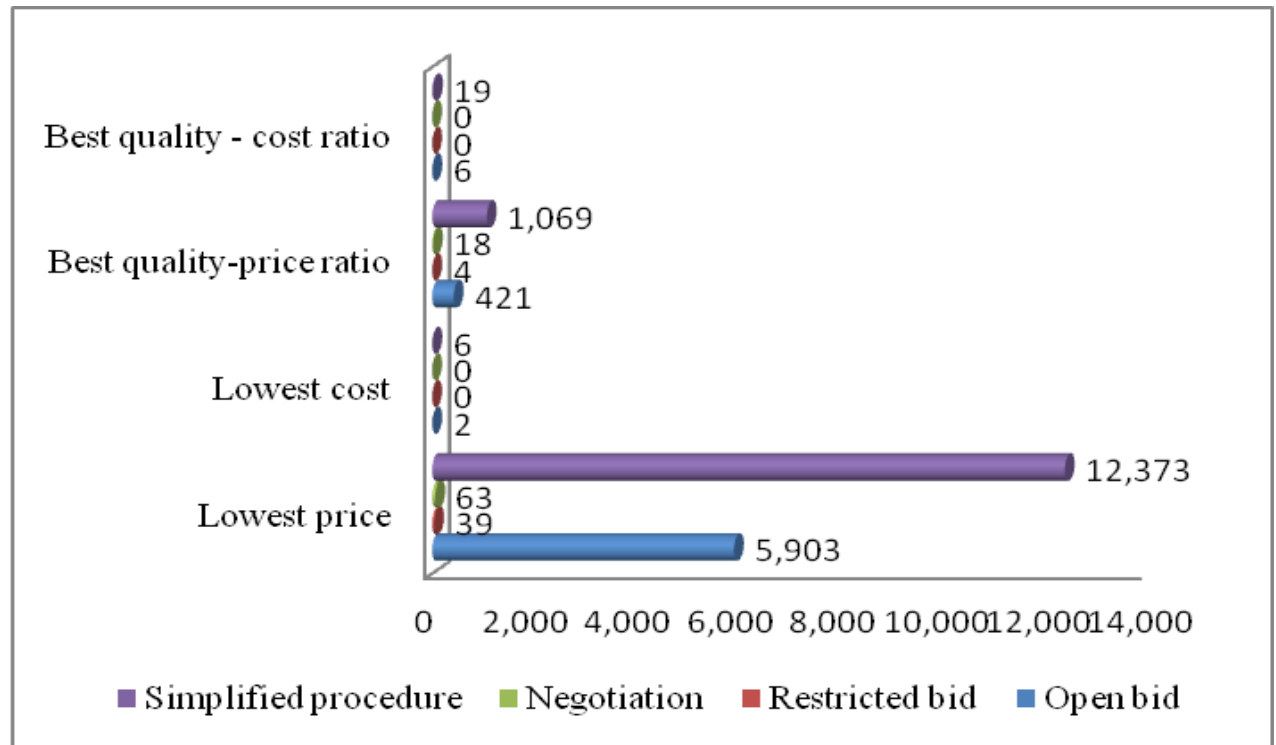

FIGURE 2: GRAPHICAL REPRESENTATION OF THE NUMBER OF PROCUREMENT PROCEDURES BY TYPE OF AWARD CRITERIA

Source: Based on the data in Table 3

To make an objective analysis of using the lowest price criterion in Romania, we will compare the use of this criterion in Romania and other EU Member States.

The weight of procurement procedures that used the lowest price criterion for the award between 2015 and 2017 in the EU Member States is shown in Table 4. 
Preda I., Simion C.P.

USE OF "THE LOWEST PRICE" AWARD CRITERION IN THE PUBLIC PROCUREMENT IN ROMANIA

This weighting indicates how contracting authorities at national level choose to award contracts, namely solely on the basis of the price, without taking into account other factors of assessment such as quality, delivery or warranty period.

TABLE 4: THE WEIGHT OF PROCUREMENT PROCEDURES THAT USED THE LOWEST PRICE CRITERION

The weight of procurement procedures that used the lowest price criterion (\%)

\begin{tabular}{|c|c|c|c|}
\hline \multicolumn{4}{|c|}{ The weight of procurement procedures that used the lowest price criterion (\%) } \\
\hline Country/Year & 2015 & 2016 & 2017 \\
\hline BE & 30 & 28 & 29 \\
\hline BG & 66 & 64 & 79 \\
\hline $\mathrm{CZ}$ & 85 & 82 & 77 \\
\hline DK & 29 & 26 & 53 \\
\hline $\mathrm{DE}$ & 54 & 52 & 67 \\
\hline $\mathrm{EE}$ & 78 & 65 & 76 \\
\hline $\mathrm{IE}$ & 7 & 7 & 17 \\
\hline$E L$ & 79 & 93 & 86 \\
\hline ES & 24 & 27 & 30 \\
\hline FR & 5 & 7 & 16 \\
\hline $\mathrm{HR}$ & 92 & 91 & 80 \\
\hline IT & 45 & 43 & 39 \\
\hline $\mathrm{CY}$ & 91 & 92 & 93 \\
\hline LV & 75 & 67 & 73 \\
\hline LT & 91 & 91 & 90 \\
\hline LU & 79 & 79 & 69 \\
\hline $\mathrm{HU}$ & 66 & 72 & 51 \\
\hline MT & 95 & 96 & 93 \\
\hline $\mathrm{NL}$ & 12 & 11 & 17 \\
\hline AT & 46 & 45 & 33 \\
\hline $\mathrm{PL}$ & 24 & 16 & 46 \\
\hline PT & 65 & 68 & 65 \\
\hline RO & 92 & 96 & 93 \\
\hline
\end{tabular}


Preda I., Simion C.P.

USE OF "THE LOWEST PRICE" AWARD CRITERION IN THE PUBLIC PROCUREMENT IN ROMANIA

\begin{tabular}{|c|c|c|c|}
\hline \multicolumn{5}{|l|}{ The weight of procurement procedures that used the lowest price criterion (\%) } \\
\hline Country/Year & 2015 & 2016 & 2017 \\
\hline SI & 76 & 78 & 62 \\
\hline SK & 88 & 85 & 92 \\
\hline FI & 50 & 46 & 54 \\
\hline SE & 56 & 53 & 74 \\
\hline UK & 8 & 4 & 12 \\
\hline IS & 83 & 75 & 89 \\
\hline LI & - & 25 & 73 \\
\hline NO & 19 & 18 & 22 \\
\hline
\end{tabular}

Source: (EC, 2018)

The graphical representation of the weight of the procedures that used the lowest price criterion for the award between 2015 and 2017 in the EU Member States is shown in Figure 3.

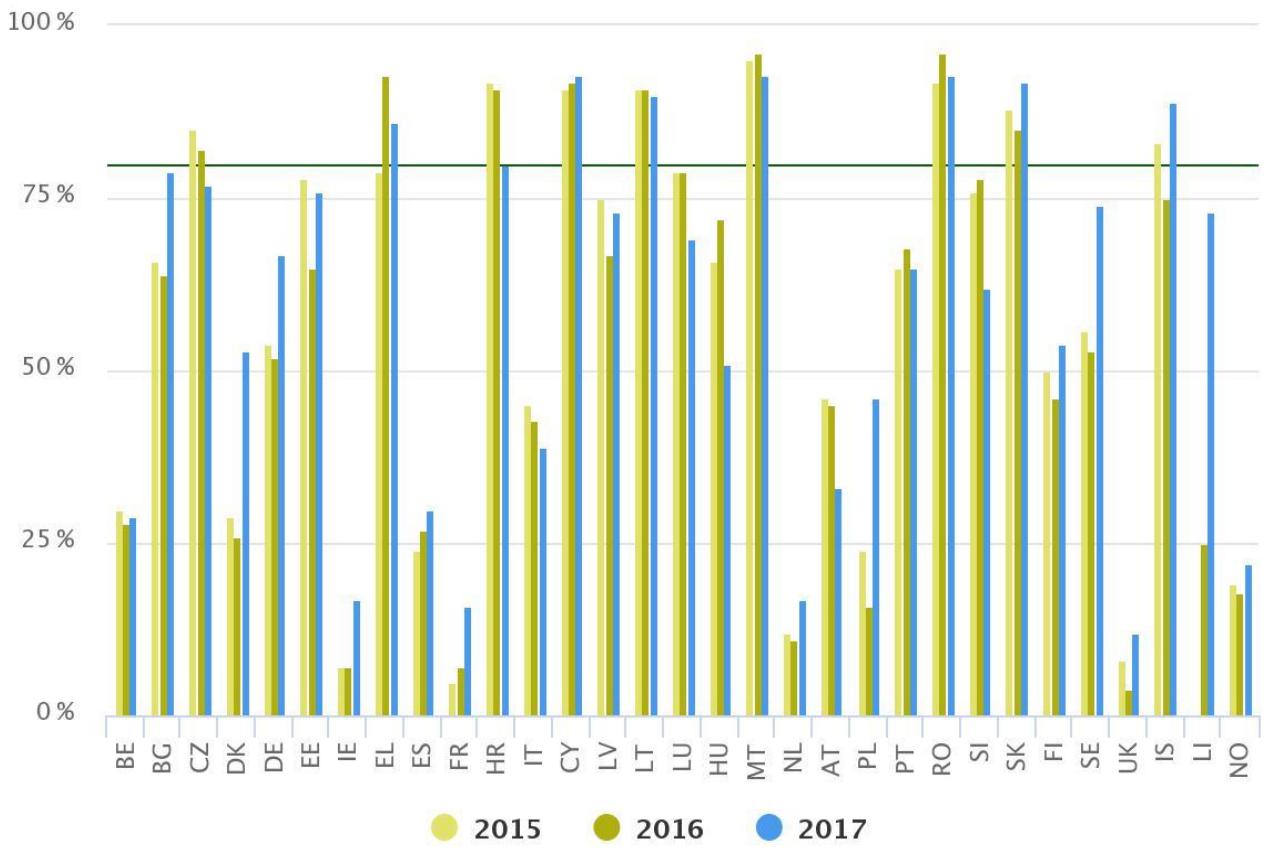

FIGURE 3: THE GRAPHICAL REPRESENTATION OF THE WEIGHT OF THE PROCEDURES THAT USED THE LOWEST PRICE CRITERION 
Source: Based on the data in Table 4

From the data presented for the period 2015-2017 it can be noticed that countries such as Malta (MT), Cyprus (CY), Hungary (HR) and Lithuania (LT) used the lowest price criterion in over $90 \%$ of the procedures.

Unfortunately, Romania was among the countries where the weight of procedures that used the lowest price criterion for award was among the highest in Europe, of over $92 \%$. In view of the above situation, the measure implemented by the National Agency for Public Procurement (ANAP) has been fully justified by means of which, starting with June 2018 , it has imposed on contracting authorities, if the estimated value of a batch or the estimated value of the largest subsequent contract exceeds the threshold of 648,288 lei, VAT excluded, to use the other three award criteria.

Countries such as Ireland (IE), France (FR), the Netherlands (NL) and the United Kingdom (UK) have very small weights, below $17 \%$, which reveals more complex procurement procedures that have also taken into account other evaluation factors except price.

\section{KNOWING MANUFACTURING COSTS - ADVANTAGE IN PROCUREMENT PROCEDURES}

Particularly important in public procurement is knowing the manufacturing costs of a manufacturer by its competitors.

In the case of procurement procedures using award criteria such as "the best quality-price ratio" or, in particular, "the lowest price", knowing the manufacturing cost and implicitly the selling price is essential because an economic operator cannot reduce the price below the cost of manufacturing, with its competitor offering a slightly lower price, winning the procedure and thus maximizing profits.

Finding competitors' costs can also be done through illegal activities such as economic espionage aimed at gaining trade secrets through theft.

To highlight the importance of knowing the manufacturing cost of competing tenderers, we exemplify the results before and after the final electronic bid stage of two open public bids using the "lowest price" award criterion, and which had as their object the supply of motor vehicles. Data are presented in Table 5. 
TABLE 5: PRICES TENDERED IN THE TWO BIDS BEFORE AND AFTER THE ELECTRONIC BID STAGE

\begin{tabular}{|c|c|c|c|c|}
\hline \multicolumn{5}{|c|}{ Bid no. 1 - object: supply of 10 refrigerating vans } \\
\hline \multirow{2}{*}{\multicolumn{5}{|c|}{ Number of participation notice published in the Romanian Electronic Public Procurement }} \\
\hline & & & & \\
\hline \multicolumn{5}{|c|}{ Estimated unit price: 78,200 lei, VAT excluded/piece } \\
\hline No. & $\begin{array}{l}\text { Name of tendering } \\
\text { economic operator }\end{array}$ & $\begin{array}{l}\text { Make and type of } \\
\text { the tendered } \\
\text { vehicle }\end{array}$ & $\begin{array}{l}\text { The unit price } \\
\text { tendered before the } \\
\text { electronic bid (lei, } \\
\text { VAT excluded/piece) }\end{array}$ & $\begin{array}{l}\text { The unit price } \\
\text { tendered after the } \\
\text { electronic bid (lei, } \\
\text { VAT } \\
\text { excluded/piece) }\end{array}$ \\
\hline 1 & $\begin{array}{c}\text { Renault } \\
\text { Commercial } \\
\text { Roumanie }\end{array}$ & Dacia Dokker & $77,718.84$ & 69,199 \\
\hline 2 & Tiriac Auto & $\begin{array}{l}\text { Ford Transit } \\
\text { Connect }\end{array}$ & 78,150 & 72,981 \\
\hline \multicolumn{5}{|c|}{$\begin{array}{c}\text { Number of participation notice published in SEAP: } 166420 / 04.0 \\
\text { Estimated unit price: } 38,000 \text { euro, VAT excluded/piece }\end{array}$} \\
\hline No. & $\begin{array}{l}\text { Name of tendering } \\
\text { economic operator }\end{array}$ & $\begin{array}{l}\text { Make and type of } \\
\text { the tendered } \\
\text { vehicle }\end{array}$ & $\begin{array}{l}\text { The unit price } \\
\text { tendered before the } \\
\text { electronic bid (lei, } \\
\text { VAT excluded/piece) }\end{array}$ & $\begin{array}{l}\text { The unit price } \\
\text { tendered after the } \\
\text { electronic bid (lei, } \\
\text { VAT } \\
\text { excluded/piece) }\end{array}$ \\
\hline 1 & Porsche Romania & Audi Q5 & $37,918.73$ & 25,410 \\
\hline 2 & Automobile Bavaria & BMW X3 & 38,000 & 25,877 \\
\hline
\end{tabular}

Source: Electronic Public Procurement System (SEAP) in Romania

From the analysis of the data in the table above, it is noted that prior to the electronic bid the economic operators tendered very close or even identical prices to the estimated price of the procedure (and implicitly to the estimated purchase value) because they hoped to be the only tenderers in the procedure and not to have to reduce the price at the electronic bid, obtaining a maximum profit. 
Knowing the costs of competitors becomes essential in the final e-bid stage when a tenderer has to reduce the price up to a level where its competitor can no longer reduce it.

The tenderer, who knows the costs of its competitors, offers the lowest price, wins the procedure and maximizes its profit, the differences being sometimes very small compared to the price of the awarded product. For example, in case of bid no. 1, the car was sold at a unit price of 69,199 lei, VAT excluded /piece, the difference between the competitors being of 3,782 lei VAT excluded/piece (weight of $5.46 \%$ of the final unit price) and in case of bid no. 2 the vehicle was awarded at a unitary price of 25,410 Euro, VAT excluded/piece, the difference between the competitors was of 467 Euro VAT excluded/piece (weight of $1.83 \%$ of the final unit price).

\section{CONCLUSIONS}

The study finds that, in 2017, most of the procedures conducted in Romania used the criterion of the lowest price (with a weight of $92.25 \%$ ) and the criterion of the best quality-price ratio (with a weight of $7.59 \%)$.

The study also found that, when using the lowest price criterion, one of the main problems faced by contracting authorities is to set the exact technical specifications right from the start of the procedures (especially for military or innovative products). In other situations, contracting authorities have the tendency to set too detailed technical specifications, making it very difficult for the interested companies to develop their tenders, the tender evaluation process, contract performance and ordered products acceptance.

At the European level, between 2015 and 2017, Romania was among the countries that had the highest rates of use of the lowest price criterion (of over 92\%). At EU level, only Malta had a larger weight than Romania. The rest of the European countries used this award criterion much less, taking into account other valuation factors other than the price.

The study also highlighted that a vulnerability of tenderers who participate in procurement procedures is knowing the cost of manufacturing by competitors. Under procurement procedures, an economic operator cannot reduce the price below the cost of manufacturing, with its competitor offering a slightly lower price, winning the procedure and thus maximizing profits. 


\section{REFERENCES}

ANAP, (2017) Agenția Națională pentru Achiziții Publice - Indicatorii de monitorizare a eficienței procedurilor de achiziție publică finalizate prin contract/acord-cadru în anul 2017, [online]. Retrieved from: http://anap.gov.ro/web/wp-content/uploads/2018/06/Indicatorii-de-monitorizare-aeficien $\%$ C8\%9Bei-procedurilor-de-achizi\%C8\%9Bie-public\%C4\%83-finalizate-prin-contract-sau-acordcadru-\%C3\%AEn-2017.pdf/ [Accessed 2 December 2018]

Baeyens, B. \& Martel, M., (2007). Budget and organization reform in Belgium: Impact on public procurement, cited in Thai, K. V. et al (2009). International Handbook of Public Procurement, p. 429, Taylor \& Francis Group

Bergman, M., A. \& Lundberg, S., (2013). Tender Evaluation and Supplier Selection in Public Procurement, Journal of Purchasing \& Supply Management vol. 19 (2013), pp. 73-83, Elsevier

Carpineti, L., Piga, G. \& Zanza, M., (2006). The Variety of Procurement Practice: Evidence from Public Procurement, [online]. Retrieved from: file:///C:/Users/ionel/Downloads/SSRN-id896748.pdf/ [Accessed 14 March 2018]

Chen, T., H., (2008). An Economic Approach to Public Procurement, Journal of public procurement, vol. 8, Iss 3, pp. 407 - 430, Emerald Insight

Cummings, G. \& Qiao, Y. (2003). The Use of Qualification-based Selection in Public Procurement: a Survey Research, Journal of Public Procurement, Vol. 3 No. 2, pp. 215-226, cited in Raymond, J., (2008). Benchmarking in Public Procurement, Benchmarking: An International Journal, vol. 15, Iss 6 pp.782-793, Emerald Insight

Dimitri, N., Piga, G. \& Spagnolo, G. (2006). Handbook of Procurement, pp. 28 - 304, Ed. Cambridge University Press

EC, (2018) European Commission. The EU Single Market - Single Market Scoreboard - Public Procurement, [online]. Retrieved from: http://ec.europa.eu/internal_market/scoreboard/performance_per_policy_area/public_procurement/inde x_en.htm/ [Accessed 2 December 2018]

Erridge, A. \& Nondi, R., (1994). Public procurement, competition and partnership. European Journal of Purchasing and Supply Management, 1(3), pp. 169-179, cited in Thai, K. V. et al (2009). International Handbook of Public Procurement, p. 430, Taylor \& Francis Group

Gansler, J., S. (1989). Affording Defense. Cambridge: MIT Press cited in Thai, K. V. et al (2009). International Handbook of Public Procurement, p. 430, Taylor \& Francis Group

Jones, D., S., (2007). The features and recent reforms of government procurement in Singapore cited in Thai, K. V. et al (2009). International Handbook of Public Procurement, p. 430, Taylor \& Francis Group Morgan, C. \& Sonnino, R., (2006). Empowering Consumenrs: the Creative Procurement of School Meals in Italy and the UK, International Journal of Consumer Studies, Journal compilation, p. 2, Blackwell Publishing.

OECD.STAT - Government at a Glance - 2017 edition - Public procurement, [online]. Retrieved from: https://stats.oecd.org/\#/ [Accessed 2 December 2018]

Romanian Law no. 98/2016 regarding public procurement

Soudry, O., (2004). Promoting economiy: electronic reverse auctions under the EC Directives on public procurement, Journal of public procurement, vol. 4, Iss 3, pp. 340 - 374, Emerald Insight Thai, K. V. et al (2009). International Handbook of Public Procurement, p.16, Taylor \& Francis Group 